\title{
PELABUHAN BANTEN SEBAGAI BANDAR JALUR SUTRA
}

\author{
Oleh Adeng \\ Balai Pelestarian Sejarah dan Nilai Tradisional Bandung \\ Jln. Cinambo No. 136 Ujungberung Bandung
}

Naskah disetujui: 12 Februari 2010

\begin{abstract}
Abstrak
Penulisan ini dimaksudkan untuk mempelajari hubungan antara kota pelabuhan dengan perkembangan kebudayaan sebagai akibat adanya interaksi antarbangsa yang menyertai kegiatan perdagangan. Selain itu, untuk mengetahui hubungan pelabuhan dengan pedalaman serta sarana transportasinya. Dalam penulisan ini digunakan metode penelitian yang berlaku di dalam ilmu sejarah, yaitu: heuristik, kritik, interpretasi, dan historiografi. Pada tahap heuristik dilakukan pengumpulan data primer dan data sekunder. Kemudian dilakukan kritik intern dan kritik ekstern untuk memastikan keotentikan dan kredibilitas. Selanjutnya data tersebut dikelompokkan menurut jenisnya. Setelah proses pemberian makna, maka sampailah pada tahap historiografi, yaitu proses penulisan kisah sejarah. Peranan dan kedudukan Banten sebagai pelabuhan jalur sutra yang perkembangannya begitu pesat tidak terlepas dari perkembangan dunia internasional, yang disebabkan oleh adanya motif ekonomi, politik, dan agama.
\end{abstract}

Kata kunci: pelabuhan, kota dagang, jalur sutra.

\section{Abstract}

This writing is intended for studying the relationship between port city and culture development as the result of international interaction which. In this writing, historical method were used, including heuristic, critic, interpretation, and historiography. On the heuristic step, the collection of primary data and secondary data were conducted. Next the internal and external critic, to make sure its authenticity and originality. And then those data were grouped according its type. After the meaning giving process, finally it reached the historiography step, a history writing step. The role of Banten as a port city for the Silk Road, which the development is very fast, affected by the international world caused by economic, politic, and religion motives.

Keywords: port, trading, silk road.

\section{A. PENDAhuluan}

Sejak zaman kuno, posisi kepulauan Nusantara menjadi tempat persilangan jaringan lalu lintas laut yang menghubungkan Benua Timur dengan Benua Barat. Teknologi perkapalan dan pengetahuan navigasi yang masih sederhana tidak mengurangi ramainya jalur pelayaran ini, yaitu dengan adanya "jalur menyusur pantai". Keadaan itu mengalami perkembangan pesat sejalan dengan dikenalnya astrolabium, ilmu bintang, dan sistem 
angin yang berlaku di Lautan Indonesia dan Lautan Cina pada umumnya dan Lautan Nusantara pada khususnya, sehingga "pelayaran samudra" dapat diselenggarakan (Kartodirdjo, 1987: 1).

Kendatipun sistem pelayaran samudra sudah dapat dilaksanakan ternyata masih tetap diperlukan adanya suatu tempat dengan jarak tertentu untuk berlabuh, guna memenuhi perbekalan-perbekalan baru yang senantiasa dibutuhkan di kepulauan Nusantara. Tempat-tempat berlabuh itu kemudian berkembang menjadi kota-kota pelabuhan serta pusat-pusat kerajaan zaman Brawijaya dan Majapahit serta dijadikannya kawasan tersebut sebagai mata rantai perdagangan sutera dari Cina ke Eropa (Kartodirdjo, 1987: 1). Walaupun barang-barang yang diperdagangkan tidak terbatas pada sutera, tetapi karena sutera merupakan barang dagangan yang dominan, maka jalur perdagangan antara dunia Timur dan dunia Barat itu disebut sebagai "jalur sutera".

Pasai sebagai Kerajaan Islam mulai memainkan peranan penting, yang menghubungkan Malaka, Jawa, dan Kerajaan-kerajaan Islam lainnya di wilayah Nusantara bagian Timur. Perkembangan lebih lanjut ialah bermunculannya kota-kota di pantai Timur Samudra Indonesia dan pantai Utara Pulau Jawa, termasuk di dalamnya kota pelabuhan Banten. Aktif memainkan peranan penting, terutama di dunia perdagangan. Kota Banten yang terletak di tepi sungai merupakan pelabuhan yang baik, sebab dapat dilayari kapal-kapal besar sampai jauh ke pedalaman. Daerah pedalaman menghasilkan beras dan bahan pangan lainnya sebagai komoditas ekspor, ditambah pula dengan pemerintahan yang bercorak Islam yang stabil, semua itu mendorong Banten sebagai salah satu kota pelabuhan yang cukup ramai dan penting, tempat berkembangnya perdagangan, agama, dan kebudayaan.

Dengan melihat perkembangan Banten sebagai kota pelabuhan, maka perlu dilakukan penelitian dengan permasalahan-permasalahan sebagai berikut. Sejak kapan Banten berperan dalam percaturan perdagangan internasional? Faktor-faktor apa yang mendukung Banten sebagai bandar niaga? Bagaimana sistem pengelolaan pelabuhan dan sistem perdagangan yang berlaku di Banten? Jenis-jenis komoditas apa yang diperjual-belikan di Banten? Bagaimana sistem pengetahuan dan teknologi transportasi yang mendukung Banten sebagai bandar niaga?

Tujuan penelitian ini adalah untuk menemukan faktor-faktor yang mendukung terbentuknya Banten sebagai kota pelabuhan di jalur sutera. Selain itu dimaksudkan pula untuk mempelajari hubungan antara kota pelabuhan dengan perkembangan kebudayaan sebagai akibat adanya interaksi antarbangsa yang menyertai kegiatan perdagangan.

Ruang lingkup penelitiannya sendiri mencakup jenis-jenis barang yang diperdagangkan, pengaturan dan pengelolaan pelabuhan, sistem perdagangan, serta sistem transportasi.

Penelitian ini menggunakan metode penelitian yang berlaku di dalam ilmu sejarah, yaitu: heuristik, kritik, interpretasi, dan historiogarfi. Pada tahap heuristik dilakukan pengumpulan data primer dan data sekunder. Setelah berhasil dikumpulkan, dilakukan kritik intern dan kritik ekstern untuk memastikan keotentik- 
annya dan kredibilitasnya. Kemudian sampailah pada tahap historiografi yaitu proses penulisan kisah sejarah.

\section{B. HASIL DAN BAHASAN}

Banten Lama, yang nama kotanya Surosowan, menjadi pusat pemerintahan kesultanan sejak 8 Oktober 1526. Menurut Babad atau sejarah Banten pupuh XIX, XXII, XXIV, pendirian kota lengkap dengan prasarananya: keraton, alun-alun, masjid, dan lain-lain dan petunjuk dari Syarif Hidayatullah (Sunan Gunung Jati) kepada putranya, Maulana Hasanuddin (Pangeran Hasanuddin) (Tjandrasasmita, 1987: 5).

Pembangunan Kota Banten sebagai City State 'Negara-Kota' sekaligus sebagai Kota Pelabuhan sejak Maulana Hasanuddin, Maulana Yusuf, dan memuncak masa Sultan Ageng Tirtayasa ditunjang oleh berbagai faktor. Faktor-faktor tersebut antara lain letak geografis yang strategis, ekologis yang menguntungkan, struktur masyarakat dengan pemerintahan yang mantap sehingga memungkinkan untuk tumbuh dan berkembang, serta memuncaknya kehidupan sosial-ekonomi, sosial-budaya/keagamaan, dan sosialpolitik Kesultanan Banten pada abad ke-16 dan 17 Masehi. Faktor-faktor yang menumbuhkembangkan Kota Banten tersebut sesuai dengan beberapa teori, seperti: Peter J.M. Nas (1986: 1336), Gideon, Sjoberg (1965: 27-31), Max Weber (1966: 66). Sebaliknya faktor-faktor itu jika ada salah satu atau dua kelemahannya dapat pula menyebabkan keruntuhan suatu kerajaan (Tjandrasasmita, 2002: 5).

Menurut Babad Cirebon dan Carita Purwaka Caruban Nagari
(CPCN), pada saat Sunan Gunung Jati pertama kali ke Banten, di daerah ini penduduknya telah menganut agama Islam hasil binaan Sayid Rakhmat yang lebih dikenal dengan sebutan Sunan Ampel.

Usaha Sunan Ampel di Banten agaknya tidak bisa dilanjutkan oleh orang lain, sehingga pada masa itu agama Islam belum tersebar luas. Hal itu kiranya karena Banten masih merupakan wilayah kekuasaan Kerajaan Sunda dan bagian terbesar masyarakatnya masih memegang teguh kepercayaan kepada leluhur, agama Hindu dan agama Budha. Jadi, agama Islam baru masuk di sekitar pelabuhan Banten atau pesisir pantai, belum masuk ke wilayah pedalaman Kerajaan Sunda.

Menurut Tome Pires pada tahun 1513 Masehi di Kota Pelabuhan Cimanuk telah ada masyarakat yang memeluk agama Islam, walaupun syahbandarnya masih kafir. Hal ini berarti abad ke-15 Masehi di wilayah Kerajaan Sunda sudah ada masyarakat yang beragama Islam. Mereka umumnya tinggal di kota pelabuhan, seperti di Banten dan Kalapa.

Hal itu dapat dipahami, karena pada waktu itu banyak pedagang asing yang telah beragama Islam datang ke Pelabuhan Banten untuk berdagang. Di situlah terjadi interaksi sosial, budaya, ekonomi, agama, bahkan bisa juga yang bersifat politik.

Seiring dengan perkembangan Pelabuhan Banten, maka semakin banyak pula orang-orang Islam yang berkunjung dan menetap di kota pelabuhan ini, sehingga lama kelamaan Banten menjadi pusat penyebaran agama Islam di Jawa Barat. Apalagi 
Kerajaan Sunda makin lemah dan sudah tidak berkuasa lagi di Pelabuhan Banten. Jadi, ibarat air terus mengalir dengan derasnya, Banten pun semakin banyak dikunjungi saudagar Islam.

Setelah Banten dipegang oleh Sunan Gunung Jati, agama Islam di Banten makin berkembang. Sunan Gunung Jati kemudian menikah dengan adik Bupati Banten yang bernama Nyai Kawunganten. Melalui tali perkawinan tersebut Bupati Banten dan rakyatnya menganut agama Islam dan berguru kepada Sunan Gunung Jati. Dua tahun kemudian (1477) dari perkawinan itu lahirlah putri Ratu Winaon dan tahun berikutnya (1478) lahir pula Pangeran Sabakingkin (Atja dan Ayatrohaeidi, 1986: 131).

Pangeran Sabakingkin, setelah naik tahta namanya berganti menjadi Pangeran Hasanuddin seperti telah disebutkan di atas, meneruskan perjuangan ayahnya, yaitu menyebarkan agama Islam di Banten. Sebagai mubaligh, Pangeran Hasanuddin digambarkan sebagai tokoh yang memasuki Banten secara damai, luwes dalam pergaulan, bertingkah laku baik, dan berbudi bahasa menarik. Oleh karena itu, ia dapat bergaul secara mudah dengan rakyat biasa dan dapat memperkenalkan agama baru, yakni Islam kepada penduduk kalangan bawah.

Selama berkuasa Sultan Hasanuddin lebih menekankan pada bidang keagamaan, sebab ayahnya (Sunan Gunung Jati) memang mempersiapkan beliau untuk menyebarkan agama Islam di samping memegang kerajaan. Cara yang dilakukan oleh Sultan Hasanudin dalam menyebarkan agama Islam adalah, ia lebih menekankan pada kebiasaan kehidupan masya- rakat sehari-hari. Maksudnya supaya ajaran agama Islam dapat diterima, dimengerti, dan dicerna oleh masyarakat Banten (Michrob, 1993: 68 dalam Wiryono, al al., 2004: 10).

Banten pun dikembangkan menjadi sebuah pelabuhan transit atau persinggahan saudagar asing seperti dari India, Cina, Parsi, dan Gujarat. Adapun komoditas perdagangan rempah-rempah yang laku saat itu adalah lada dan merica, terutama sangat laku di pasaran Asia dan Eropa. Para pedagang asing tersebut membawa barang dagangan dari daerah asalnya, misalnya pedagang dari Cina membawa kain sutra, porselen, dan benang sulam. Sistem perdagangan yang berlangsung saat itu masih menggunakan sistem barter atau tukar tambah.

Menurut Babad Banten, Sunan Gunung Jati kembali lagi ke Cirebon setelah kekuasaannya diberikan kepada puteranya, yang bernama Pangeran Hasanuddin (Sultan Hasanuddin). Selanjutnya dalam Babad Banten disebutkan bahwa usaha Islamisasi di Banten berhasil secara menakjubkan. Sultan Hasanuddin berhasil mengislamkan masyarakat Banten Ilir, di antaranya sebanyak 800 orang resi (pertapa) masuk agama Islam dengan sukarela (Ambary, 1997: 48).

Sultan Hasanuddin memerintah Banten sejak tahun 1552, wafat pada tahun 1570 dan dimakamkan di samping Mesjid Agung Banten. Sebagai penggantinya adalah putranya yang bernama Maulana Yusuf. Dalam kepemimpinannya, ia melanjutkan apa yang telah dirintis oleh ayahandanya, yakni Sultan Hasanuddin. Selain itu, beliau meningkatkan keamanan wilayah dengan jalan membangun sebuah kubu pertahanan atau benteng 
pertahanan, memperluas atau mengembangkan kota, serta lebih meningkatkan bidang pertanian (Djajadiningrat, 1983: 38). Meningkatkan bidang pertanian, mengingat hasil rempah-rempah dari Banten sangat dibutuhkan oleh para pedagang asing.

Maulana Yusuf mempunyai dua orang putra, yaitu Pangeran Muhammad dan Ratu Winaon dari hasil pernikahan dengan Ratu Hadidjah. Maulana Yusuf meninggal dunia pada tahun 1580 dan dimakamkan di Pakalangan Gede, dekat Kampung Kasunyatan sekarang. Oleh karena itu, kemudian ia diberi gelar "Pangeran Panembahan Pekalangan Gede atau Pangeran Pasarean". Pengganti Maulana Yusuf adalah putranya yang bernama Pangeran Muhammad, yang ketika itu usianya baru menginjak 9 tahun.

Untuk memimpin sebuah kerajaan yang begitu besar tidak mungkin dipegang oleh seorang Pangeran yang usianya masih belia atau dapat dikatakan masih kanak-kanak. Oleh karena itu, untuk mengisi kekosongan pimpinan sambil menunggu Pangeran dewasa, maka sementara waktu kerajaan dipegang atau dijalankan oleh Mangkubumi Jayanegara. Setelah Pangeran Muhammad dewasa, pemerintahan diserahkan oleh Mangkubumi Jayanegara kepada ahli warisnya, yakni Pangeran Muhammad.

Pangeran Muhammad atau disebut pula Sultan Maulana Muhammad dikenal sebagai orang yang saleh dan taat menjalankan ajaran agama Islam dan mempunyai perhatian yang besar terhadap kehidupan keagamaan. Pangeran (Sultan) banyak menulis kitab-kitab yang kemudian dibagikan kepada orang yang membutuhkan.
Untuk sarana ibadah, Sultan Maulana Muhammad membangun mesjid-mesjid sampai ke pelosok-pelosok, yang penduduknya menganut agama Islam.

Sebagai pengganti Maulana Muhammad, kemudian diangkat putranya yang kelak bernama Sultan Abdul Mufakhir Mahmud Abdulkadir (15961651). Dialah penguasa pertama di Pulau Jawa yang mendapat gelar Sultan dari penguasa Mekah (Arab), yaitu tahun 1636. Mengingat usia beliau masih kecil (5 bulan), maka sementara waktu pemerintahan dipegang oleh Mangkubumi Jayanagara. Dalam menjalankan roda pemerintahannya, ia sangat bijaksana dan setiap akan mengambil keputusan selalu bermusyawarah dengan pembesarpembesar kerajaan. Bertepatan dengan itu, datanglah Belanda ke Banten (1596) dengan maksud berdagang.

Perlu dijelaskan, sebelum kedatangan pedagang dari Belanda, ternyata di Banten telah ada pedagangpedagang yang berasal dari Portugis, yang kemudian diikuti oleh orang Inggris. Mereka membuat loji-loji dan kemudian Belanda pun turut mendirikan loji. Kedatangan mereka (Portugis, Inggris, dan Belanda) ke Banten sama tujuannya, yakni berdagang, mencari rempah-rempah, dan lada; karena di negara mereka barang-barang tersebut sangat dibutuhkan. Oleh karena tujuan mereka sama, mau tidak mau terjadi persaingan yang ketat dan menjurus menjadi persaingan yang tidak sehat. Persaingan ini ternyata dimenangkan oleh pihak Belanda, karena mereka menggunakan cara yang licik, yakni menggunakan kekuatan militer.

Pada tahun 1598 datang lagi orang-orang Belanda ke Banten. Rom- 
bongan ini di bawah pimpinan Jacob van Neck dan van Waerwyek. Kedatangan orang Belanda di bawah pimpinan van Waerwyek kali ini dapat mengambil hati para pembesar Banten, sehingga mereka mendapat izin untuk mendirikan kantor dagang di Banten. Keberhasilan dua ekspedisi dagang Belanda ini membuka jalan lebar-lebar kepada orang-orang Belanda untuk kembali berdagang ke Indonesia.

Pada masa pemerintahannya, Sultan Abdul Mafakhir Mahmud Abdulkadir berusaha meningkatkan kesejahteraan rakyat dengan jalan meningkatkan hasil pertanian, perdagangan, bidang politik, dan keamanan. Selain itu, untuk mempersiapkan penggantinya, beliau mengangkat putranya sebagai putera mahkota dengan nama Sultan Abdulma'ali Ahmad. Namun, karena Sultan Abdulma'ali Ahmad meninggal dunia, maka setelah Abdul Mafakhir Mahmud Abdul Kadir wafat, diangkatlah cucunya, Pangeran Surya, putera Pangeran Abdulma'ali Ahmad, sebagai penguasa Banten. Pangeran Surya bergelar Pangeran Adipati atau Adipati Anom. Penobatan Pangeran Surya menjadi Sultan Banten ke-5 terjadi pada tanggal 10 Maret 1651. Pangeran Surya kemudian mendapati gelar dari Mekah, yang lengkapnya yakni Sultan Abulfath Abulfattah. (Djajadiningrat, 1983: 205).

Sultan Abulfath Abdulfattah selain mengadakan perbaikan-perbaikan terhadap Keraton Surosowan, juga membuat keraton baru di Tirtayasa, yang terletak di sebelah utara Kota Banten. Keraton inilah yang dijadikan tempat sultan melaksanakan kegiatan sehari-hari. Sejak pindah ke Tirtayasa, beliau lebih dikenal dengan sebutan Sultan Ageng Tirtayasa.

Selama masa pemerintahannya, Sultan Ageng selalu dihadapkan pada perjuangan yang gigih untuk mempertahankan eksistensi dan kemerdekaan Kesultanan Banten dari ancaman armada Kompeni Belanda, yang mempunyai tempat kedudukan di Batavia (dulu Jayakarta dan sekarang Jakarta) sejak tahun 1610 . Berkat perjuangannya itu, Sultan Ageng Tirtayasa ditetapkan oleh Pemerintah Republik Indonesia sebagai Pahlawan Nasional.

Sejak abad ke-16 hingga awal abad ke-19 Kesultanan Banten memperlihatkan keberadaannya sebagai Kerajaan Islam di Nusantara. Kesultanan ini mengalami masa kejayaan pada abad ke-17, namun juga pada akhir abad tersebut sebagai awal kemundurannya.

\section{Banten sebagai Bandar Niaga}

Banten memang sebuah kota yang tidak dapat dilepaskan dari citranya sebagai Kota Pelabuhan. Sejak awal, kehidupan "perairan" sudah melekat dengan kota ini. Adapun cikalbakal Kota Banten berawal ketika Sunan Gunung Jati dengan pasukan Islam dari Demak menyerang Banten yang pada waktu itu masih di bawah kekuasaan Kerajaan Sunda. Jatuhnya Banten ke tangan pasukan Islam tersebut boleh dikatakan merupakan cikal bakal Banten sebagai Kerajaan Islam atau disebut pula sebagai Bandar Niaga (Kota Pelabuhan) yang cukup besar dan ramai serta banyak dikunjungi pedagang dalam negeri dan luar negeri.

Hal ini terbukti seperti pihak Cina rupanya merasa tertarik dengan 
Pelabuhan Banten ini. Hal itu terlihat selain dari kesediaan mereka membuat mercusuar, juga membuka perwakilan dagang Cina untuk Nagari Singapura. Pembukaan itu memang didasarkan pada kenyataan bahwa Banten merupakan pelabuhan yang ramai. Setiap orang berjual beli dan banyak perahu berlabuh di Pelabuhan Banten. Mereka itu, di antaranya berasal dari Cina, Arab, Persia, India, Malaka,Tumasik, Pasai, Jawa Timur, dan Palembang.

Keramaian itu tidak lepas dari perkembangan perdagangan internasional, khususnya yang berhubungan dengan"Jalur Sutra“. Telah diketahui bahwa hasrat akan sutra Cina yang berkilauan, yang katanya senilai emas, membuka jalan untuk jalur sutra melalui daratan sepanjang $6.400 \mathrm{~km}$ melintasi Asia yang berlangsung berabad-abad. Dengan demikian, serangkaian perdagangan kuno itu tidak hanya memperdagangkan sutra semata tetapi juga rempah-rempah, buahbuahan, porselan, mesiu, dan lainlainnya, bahkan lebih jauh sutra ini menyebabkan kontak budaya dan agama.

Sayangnya, jalur sutra melalui daratan ini merupakan rute yang sulit. Banyak rintangan menghadang, seperti badai pasir, cuaca panas, cuaca dingin, bahkan para penyamun. Melihat kenyataan yang demikian, para pedagang berusaha mencari jalan altenatif yang lebih mudah dan aman. Upaya itu menemui bentuknya dalam sistem transportasi laut, setelah sistem pelayaran laut yang lebih baik ditemukan (mengenal perkembangan jalur pelayaran, lebih jauh lihat Sejarah Nasional Indonesia jilid III. Yang jelas, faktor ekonomi ini menjadi motivasi yang kuat dibukanya pusat-pusat perdagangan baru, seperti dijelaskan oleh Sedyawati, at. al. (1995: 2) berikut ini:

Sudah sejak lama terjadi perdagangan antara kawasan dunia "barat" dan "timur". Para pedagang yang melintasi bebagai negara, menempuh beribu-ribu mil, didorong untuk memperoleh barang-barang dagangan dari negeri-negeri jauh, yang dinilai amat berharga. Bagi orangorang Eropa, daya tarik utama dari dunia Timur adalah sutra dan rempahrempah. Berbagai jalan ditempuh untuk menghubungkan Timur dan Barat dalam upaya perdagangan itu. Jalan darat melintasi dataran Asia ditempuh dengan kuda (untuk daerah padang rumput) atau unta (untuk daerah padang pasir), sedangkan jalan laut melalui Laut Tengah, Samudera India, dan Laut Cina Selatan ditempuh dengan kapal.

Dengan ditemukannya jalur sutra "lewat laut", maka muncul pelabuhan-pelabuhan baru sebagai pusat-pusat pedagangan yang membentang dari Cina sampai Eropa, di mana Nusantara termasuk ke dalam jaringan perdagangan tersebut. Hal itu dapat dibuktikan melalui sumber sejarah Majapahit yang berasal pada masa Hayam Wuruk yang menyebutkan 33 tempat yang dinamai nusa (artinya tempat-tempat di sisi laut) dan 47 tempat yang disebut "naditirapradesa" (artinya tempat-tempat di tepi sungai), yang berperan sebagai pangkalan dalam jaringan lalu lintas air (Sedyawati, 1995: 350).

Begitu juga dengan Banten, letak geografisnya di daerah pesisir pantai Pulau Jawa tentu saja termasuk ke dalam mata rantai dalam perda- 
gangan internasional (jalur sutra) pada masa itu. Mengenai peranan Banten sebagai bandar niaga ini dijelaskan oleh Mills (1970: 14-23) dengan memberikan tafsiran bahwa Cheng Ho ketika melakukan ekspedisi ketujuh antara tahun 1431-1433 dalam perjalanan kembali ke Surabaya, ke Palembang melalui beberapa pelabuhan di pantai utara Jawa, yaitu Tanmu (Demak), Wuchueh (Pekalongan), Che-li-wen (Cirebon), dan Chia-lu-pa (Sunda Kelapa), Banten.

Banten sebagai bandar niaga yang berperan dalam perdagangan internasional tentunya tidak dapat disangkal lagi. Kedatangan kapal-kapal asing di Banten memperjelas keterkaitan Banten dalam jaringan internasional. Analogi dengan pelabuhanpelabuhan Banten, Pontang, Tanggerang, Kalapa, dan Chi Manuk yang diberitakan Tom Pires (15121515), sebagai pelabuhan Kerajaan Sunda maka Bandar Cirebon pada masa masuk kerajaan itu mungkin juga telah masuk dalam jaringan pedagangan internasional atau pasar dunia, sekalipun tidak seperti Pelabuhan Banten dan Kalapa (Tjandrasasmita, 1987: 7).

Demikianlah, sejak Banten dibangun oleh Sunan Gunung Jati (Syekh Syarif Hidayatullah) dan beliau memegang kekuasaan di Banten, Bandar Banten semakin ramai dan baik untuk perhubungan laut antara ParisMesir dan Arab, Cina, Campa dan pelabuhan lainnya. Kepesatan perkembangan Pelabuhan Banten didukung pula oleh Politik Ekspansi Kerajaan Islam (di bawah pimpinan Demak) untuk menguasai pelabuhan-pelabuhan Kerajaan Pajajaran. Setelah Banten dikuasai (tahun 1526) dan Sunda
Kelapa (tahun 1527) maka seluruh pesisir utara Jawa Barat telah ada dalam tangan kekuasaan Islam. Akibat politik ini sudah tentu bandar-bandar tersebut, termasuk Cirebon merupakan tempat jaringan perdagangan intenasional atau pasar dunia yang menjadi sumber penghasilan kerajaan-kerajaan Islam yang sedang tumbuh dan berkembang yang terbentang dari Demak, Cirebon hingga Banten (Tjandrasasmita, 1987: 7).

\section{Hubungan Pelabuhan dengan Pedalaman}

Kota-kota pelabuhan biasanya berperan sebagai pusat ekonomi di wilayahnya, dengan fungsinya sebagai jalur impor dan ekspor ke daerah pedalaman yang terpencil, yang dihubungkan dengan jalan sungai atau darat. Hal itu sejalan dengan pendapat Sudjana, yang menyatakan bahwa terbentuknya pelabuhan sangat dimungkinkan oleh adanya kebutuhan jasa angkutan, berkenaan dengan adanya arus perdagangan melalui transportasi kelautan (Sudjana, 1995: 1). Berangkat dari asumsi itu, suatu pelabuhan minimal harus memenuhi tiga kriteria dasar yang harus berlangsung dan berlanjut, yaitu:

a. Adanya hubungan antara pasar dunia dengan pasar domestik.

b. Adanya hubungan antara pelabuhan dengan daerah pedalaman dalam konteks keluar masuknya barang, terbentuknya jalur-jalur transporttasi, dan terbentuknya pusat-pusat pengumpulan barang dagangan di tempat-tempat tertentu.

c. Hubungan antara kegiatan pelabuhan dengan pembentukan Kota Pelabuhan itu sendiri. 
Demikian pula halnya dengan Banten, sebagai kota pelabuhan Banten merupakan tempat yang menghubungkan dua dunia, yaitu daratan dan lautan. Dari sudut ekonomi, Pelabuhan Banten ini berfungsi sebagai tempat menampung surplus dari wilayah pedalaman untuk didistribusikan ke tempat-tempat lain yang membutuhkan. Begitupun sebaliknya, Pelabuhan Banten pun berfungsi sebagai tempat penampungan barang-barang dari tempat-tempat lain yang tidak dapat dihasilkan oleh wilayah pedalaman dan sangat dibutuhkan.

Melihat kenyataan yang demikian, Sedyawati, et al. (1995: 5) menulis:

Suatu pusat pemukiman yang disebut kota pada dasarnya bukanlah suatu unit bisa menghidupi dirinya sendiri. Bahwa kota ditandai oleh penduduk yang terutama bekerja di sektor nonpertanian memberi arti bahwa kehidupan kota hanya dapat dimengerti dalam kaitannya dengan pusat-pusat pemasok bahan mentah di wilayah belakangnya.

Adanya kebutuhan yang timbalbalik itu membuat pelabuhan dan pedalaman pada posisi saling membutuhkan, satu dan lainnya saling menopang. Untuk itulah sarana dan prasarana transportasi dibangun agar memudahkan arus barang, baik dari pelabuhan maupun ke pelabuhan. Upaya ke arah itu terlihat dari apa yang ditulis oleh Ekadjati, at al. (1991: 45) seperti berikut:

Hubungan ke daerah pedalaman terjalin melalui sungai dan jalan darat. Bahwa sungai di Banten berperan sebagai jalan lalu lintas yang dapat dilayari perahu atau kapal ke arah pedalaman, disaksikan oleh Tome Pires pada tahun 1513 (Cortesao, 1994: 183). Dari Pakuan menuju Ciampea dan Rumpin, yang kemudian biasanya perjalanan dilanjutkan melalui Sungai Cisadane terus ke Pontang, Cikande, dan Tangerang di pesisir Utara Adapun dari Pakuan ke Kalapa digunakan jalur Sungai Ciliwung yang dapat dilayari dari Pakuan dan dapat ditempuh dalam waktu dua hari perjalanan. Oleh karena itu, Pelabuhan Kalapa dapat dianggap sebagai gerbang masuk ke Pakuan.

Pelabuhan Banten memang didukung oleh wilayah pedalaman yang dapat diandalkan sebagai pemasok bahan-bahan pertanian. Daerah pedalaman yang mengelilingi Banten merupakan wilayah penyangga, yang tanahnya subur dan terdiri atas dataran rendah, dataran tinggi, bahkan daerah pegunungan dengan beberapa buah gunung, seperti Gunung Honje dan Gunung Kancana. Dari wilayah ini dihasilkan produksi pertanian dalam jumlah besar, seperti sayur-mayur, buah-buahan, lada, padi, tarum atau indigo. Kayu pun menjadi barang komoditi ekspor yang banyak dihasilkan dari daerah pedalaman ini.

Dari produksi pertanian yang berasal dari daerah pedalaman ini, Banten menjadi pelabuhan yang ramai sebab bahan-bahan pertanian itu sangat dibutuhkan oleh masyarakat internasional. Kenyataan ini yang menjadikan Banten terkenal sebagai salah satu penghasil pertanian di Jawa.

Dengan banyaknya para pedagang dari manca negara ke Pelabuhan Banten, tentu saja banyak pula barangbarang yang berasal dari luar masuk ke 
Banten. Barang-barang itulah yang sangat dibutuhkan oleh masyarakat di wilayah pedalaman, sebab masyarakat pedalaman tidak memprodusi barangbarang tersebut. Adapun barang-barang tersebut meliputi barang-barang yang asing dan menarik, yang pasti barangbarang itu belum dapat diproduksi oleh masyarakat di pedesaan, seperti tekstil halus seperti sutera dan barang-barang keramik halus. Selain barang-barang impor, ada juga barang produksi khas daerah pantai yang sangat dibutuhkan oleh masyarakat pedalaman, yaitu garam, terasi, dan ikan asin.

Perkembangan Banten sebagai kota pelabuhan didukung oleh sistem pemerintahan yang cukup baik, serta adanya jalan-jalan darat meskipun kondisinya belum tentu baik. Jalan darat yang menghubungkan Kota Banten dengan daerah pedalaman mungkin sekali sudah ada sejak masa Kerajaan Pajajaran (Zuhdi, 1996: 2).

Luasnya jaringan jalan darat itu masih ditambah dengan adanya jalur transportasi sungai yang menghubungkan pusat-pusat ekonomi, yang telah mendorong para petani, pedagang, dan pengrajin untuk meningkatkan aktivitas mereka. Kegiatan para petani dan pengrajin mengikuti perkembangan perdagangan di pelabuhan. Pantaslah bila dikatakan bahwa Banten merupakan sebuah Kerajaan Maritim atau sebuah Kerajaan Islam.

\section{Sarana Transportasi}

Sarana yang sangat menunjang dalam aktivitas perniagaan ialah alat transportasi. Untuk kerajaan-kerajaan di wilayah pantai, alat transportasi yang paling utama adalah perahu (Rahardjo, et al. 1994: 29). Mengenai alat tranportasi itu, para ahli antropologi memperkirakan bahwa perahu sudah dipergunakan manusia sejak kurang lebih 25.000 tahun yang lalu, ketika manusia purba dari daratan Asia Tenggara berimigrasi, menyebar ke pulau-pulau di selatan sampai ke Irian, Australia, dan Pasifik.

Demikianlah teknologi pembuatan perahu telah lama dikembangkan oleh penduduk di pesisir pantai dan di daerah-daerah yang banyak sungainya. Perahu sebagai alat transportasi mempunyai fungsi dan peranan sosial yang penting, baik sebagai sarana utama dalam mata pencaharian hidup maupun sebagai sarana kekuatan politik dalam bentuk armada perang.

Begitu juga dengan Banten, selain geografisnya yang strategis masyarakatnya pun memiliki tradisi maritim yang kuat. Posisinya di jalur perdagangan internasional yang menghubungkan jalur niaga dari Malaka ke Maluku mendorong Banten untuk menjadi pelabuhan transito. Keadaan itu didukung pula oleh kondisi masyarakat Banten yang telah mempunyai tradisi maritim yang bentuknya berupa teknologi pembuatan perahu. Kemampuan itu melahirkan berbagai jenis perahu sepeti perahu layar, perahu bercadik, perahu lesung, dan rakit. Pengetahuan, kemahiran, dan pengalaman mereka telah dapat menguasai kesukaran alam laut, sehingga perahuperahu yang dihasilkan bentuknya disesuaikan dengan jenis keperluannya. Jenis perahu untuk menangkap ikan di pesisir pantai dan di muara-muara tentunya berbeda dengan perahu-perahu yang digunakan di laut yang dalam. Begitupun, untuk jenis perahu sebagai alat pengangkut barang dan penumpang jarak dekat berbeda dengan perahu untuk pelayaran jarak jauh. 
Kondisi objektif Banten yang seperti itu menjadikan Banten sebagai kerajaan maritim dengan pelabuhannya yang besar dan ramai. Mengenai hal itu Tome Pires mencatat bahwa pada tahun 1513 merupakan sebuah kota pelabuhan yang baik, setiap waktu ada 3 atau 4 Jung (sejenis perahu besar) yang berlabuh di sana, sedangkan Lancara (sejenis perahu yang cepat jalannya) banyak berlabuh. Junk dapat mudik hingga sejauh 9 mil menyusuri sungai yang mengalir di sana (Ekajati, et al., 1984: 90 ; Dartono, 1991: 16).

Dari catatan Tome Pires tersebut, tidak berlebihan jika dikatakan Banten merupakan pelabuhan yang besar dan ramai, jauh lebih besar dan lebih ramai bila dibandingkan dengan pelabuhan lainnya. Hal itu didasarkan pada besar kecilnya sebuah pelabuhan pada masa itu, yang dinilai atas kemampuannya untuk dilayari jenis perahu Junk. Pelabuhan Banten yang didukung oleh adanya Sungai Cibanten dapat dilayari oleh perahu Junk sejauh 9 mil (Corteseo, 1967: 186).

Junk memang merupakan alat transportasi yang terkenal dimanamana. Junk di samping dijadikan sebagai ukuran untuk menentukan besar ke-cilnya sebuah pelabuhan, juga dipakai sebagai alat pengukur kekuatan suatu kerajaan. Semakin banyak perahu Junk yang dimiliki oleh sebuah kerajaan, maka kerajaan itu dinilai sebagai kerajaan yang besar. Sebagai ilustrasi, Kerajaan Sunda pada masa itu hanya memiliki enam buah Junk. Perlu ditambahkan bahwa pada masa itu Junk yang dimiliki oleh para saudagar Cina sangat terkenal. Tjiptoatmoyo (1983:
91) mengutip pendapat Eduard Sebberg tentang Junk Cina sebagai berikut:

Junk Cina sangat menarik perhatian. Tinggi haluan dan buritannya tidak sama, sedangkan bagian tengahnya sangat rendah. Saya melihat di atas buritan terdapat sejumlah rumah-rumah kecil dan cukup mencolok, juga umbul-umbulnya yang berwarna coreng-moreng, sedangkan kedua layarnya yang lebar dan tebal terbuat dari sejenis daun rumput yang dianyam.

Sebagaimana perahu Junk, perahu Lancara pun termasuk perahu muatan barang (kargo) yang mempunyai ukuran besar. Dalam uraian mengenai perdagangan Kerajaan Sunda dengan Malaka, Tome Pires menjelaskan bahwa barang-barang kamoditas Sunda diangkut dengan Lancara, yaitu sejenis kapal yang berkapasitas sampai 150 ton (Cortesao, 1967: 167).

Bagi sebuah kerajaan maritim seperti Banten, perahu tidak saja dipakai sebagai sarana transportasi dagang semata, tetapi juga digunakan sebagai armada perang. Armada perang Banten pernah dikirim ke Demak untuk membantu Demak dalam upayanya menumpas armada Prabu Rangga Premana (Ratu Upiturung). Pasukan Cirebon itu bergabung dengan pasukan Banten, Kalapa, dan Demak yang kesemuanya mencapai 3.007 buah armada perahu (Atja dan Ayatrohaedi, 1986: 57).

Catatan Tome Pires yang menyatakan dua buah jenis perahu saja yang terdapat di Pelabuhan Banten terasa janggal dan tidak mencerminkan Banten sebagai pelabuhan yang besar dan ramai serta didukung oleh masyarakat yang telah memiliki tradisi 
maritim. Mengenai keraguan atas kesaksian Tome Peres, Djuwita (1994: 5) menulis:

Cukup menarik bahwa Pires maupun pengunjung-pengunjung bangsa Eropa lainnya yang datang sebelum abad ke-16, tidak pernah mencatat situasi sarana lalu lintas. Hal ini memberi keyakinan, bahwa mereka tidak pernah mengadakan perjalanan yang terlalu jauh dari kapal-kapal mereka untuk melihat langsung situasi di kawasan pedalaman.

Tenyata kesangsian itu dibenarkan oleh Tjiptoatmodjo dengan mengemukakan catatan Kompeni dari awal abad ke-17, yang memuat nama-nama perahu di Jawa. Nama-nama perahu itu ialah Contingh (perahu Canting Jawa berukuran kecil dan bertiang satu), Tiang (sejenis perahu besar), Gorap (perahu bertiang dua), Galjoot (perahu layar berukuran lebar dan datar dengan satu atau dua tiang), dan Gallion (perahu layar besar dengan tiga atau empat tiang dan geladak yang tinggi).

Pelayaran wilayah Asia dan Internasional menghubungkan wilayah Asia di luar Nusantara dengan Eropa. Adapun pelayaran antarpulau menghubungkan pejalanan melalui Laut Jawa tetapi tidak keluar dari kawasan Melayu Indonesia, sedangkan pelayaran lokal adalah pelayaran di kawasan pantai utara Jawa.

Kapal-kapal VOC yang berlayar ke Jawa memiliki buritan yang luas dengan kapasitas \pm 1.000 ton. Ukuran yang lebih kecil dari itu, yaitu sekitar 200-600 ton merupakan kapal-kapal yang dinahkodai pedagang Inggris dari India dan nahkoda Cina dari Propinsi Ukien yang membawa barang-barang kelontong. Adapun kapal-kapal pribumi ialah Goting (Jawa) dengan ukuran bervariasi antara 20-200 ton untuk pelayaran antarpulau. Untuk pelayaran lokal dilayani oleh kapal dengan ukuran B-20 ton dan untuk operasi di perairan dangkal biasanya dilakukan oleh kapal-kapal yang dasarnya datar, kapal sangat gesit di perairan. Dari semua kapal pribumi yang paling sering ditemukan adalah kapal Mayang Jawa, yang sebenarnya jenis perahu untuk memancing.

Dengan datangnya kapal jenis Shallop dan Brigantine, lama kelamaan Kapal Junk, Pangjava, dan Lancara hilang dari perairan. Mengenai hal ini Knaap (1995: 8) menjelaskan: Selama abad ke-17, jenis-jenis kapal ini hilang dari lautan dan pada abad ke-18 perannya sudah diambil alih oleh model kapal Shallop dan selebihnya oleh jenis kapal Brigantine. Kemudian masih sulit untuk membuktikan mana yang lebih baik di antara jenis kapal dari Eropa dengan jenis-jenis kapal yang telah ada di Asia Tenggara. Perlengkapan peralatan tentunya merupakan elemen penting, di samping kemudi pada buritan kapal dan konstruksi kapal.

Selanjutnya, yang perlu juga diperhatikan ialah hampir seluruh kapal pada masa itu dilengkapi dengan senjata. Kapal besar dengan buritan yang luas membawa peralatan perang yang berat, yang terdiri atas: 22 senjata canon, 8-10 senjata berodong, dan 40 pucuk pistol. Kapal model Shallop dipersenjatai rata-rata dengan 4 canon, 1 senjata berodong, dan 7 pistol. Kapal Mayang tidak membawa canon, tetapi mempunyai sebuah senjata berodong dan 2 pucuk pistol di dalamnya. Perkiraan senjata api pada kapal-kapal di sektor swasta di Jawa tidak kurang 
dari 5.000 canon dan 20.000 pucuk pistol (Knaap, 1995: 8).

Dari uraian di atas dapat ditarik suatu generalisasi bahwa Pelabuhan Banten sebagai pelabuhan transit dilabuhi oleh berbagai jenis perahu, baik yang berukuran besar maupun kecil. Perahu (kapal) yang berukuran besar di antaranya meliputi: Junk, Lancara, Pangjava, Brigantine, Shallop, dan Pinisi. Adapun perahu kecil meliputi Pencalong, Cunea, Mayang, Lesung, Sampan, Sope, Jegong, Tembon, Bondet, Konting, Jukung Katir, Prawean, Lete, Janggolan, dan Lambo. Secara umum perahu-perahu yang ada di sepanjang pantai Pulau Jawa dan Madura, juga terdapat di pelabuhan Banten.

\section{PENUTUP}

Terbentuknya dan berperannya Banten sebagai pelabuhan niaga tidak lepas dari perkembangan dunia internasional, yang disebabkan oleh adanya motif ekonomi, politik, dan agama. Ketiga unsur itu membentuk suatu formula yang berperan sebagai prime mover yang melandasi perilaku dan aktivitas setiap bangsa. Motif ekonomi mendorong berbagai bangsa untuk mencari komoditas yang bernilai tinggi, tidak peduli sejauh apa pun keberadaan komoditas itu. Hasrat ini memacu teknologi perkapalan dan navigasi yang mendorong pencarian wilayah-wilayah baru. Motif politik menempatkan bangsa-bangsa pendatang (yang secara relatif memiliki berbagai keunggulan) sebagai bangsa yang selalu berusaha merebut dan memaksakan hegemoninya. Adapun faktor agama melahirkan perasaan sebagai "bangsa yang paling beradab", yang mempunyai tugas suci "memperadabkan bangsabangsa yang masih primitif". Unsurunsur ekonomi, politik, dan agama merupakan daya dorong dan daya dukung bagi bangsa-bangsa untuk bekerja sama, berkompetisi, bahkan berperang.

Peranan Banten sebagai bandar niaga atau kota pelabuhan di "Jalur Sutra" hendaknya dipahami pada konstelasi perkembangan dunia internasional itu. Pada konteks itulah, peranan Banten sebagai Kota Pelabuhan (sebagaimana, kota-kota pelabuhan di kota lain) dapat dikatakan mempunyai tiga peran, yaitu sebagai centre of change, centre of integration, dan centre of culture.

Sebagai pusat perubahan, Banten memulai dengan dirinya sendiri. Hal itu tampak dari keberadaan Banten yang semula di bawah kekuasaan Kerajaan Sunda, lambat laun berubah menjadi Kota Pelabuhan dan menjadi sebuah kerajaan bercorak Islam. Perubahan itu disebabkan oleh faktor eksternal dan internal. Faktor eksternal berupa semangat dunia yang mendorong ditemukannya jalur-jalur pelayaran baru yang secara otomatis membuka wilayahwilayah baru, di mana Banten merupakan satu di antara mata rantai yang terbentuk. Adapun faktor internal berupa sumber daya alam dan manusia. Sumber daya alam Banten memang sangat mendukung terbentuknya sebagai Kota Pelabuhan. Kondisi pantainya yang landai, ditambah lagi dengan adanya sungai-sungai yang dapat dilayari sampai jauh ke pedalaman, dan potensi wilayah pedalamannya yang menyediakan "komoditas ekspor" merupakan daya dukung yang meneguhkan Banten sebagai Kota Pelabuhan. 
Namun demikian, tanpa dukungan sumber daya manusia, sumber daya alam itu tidak berarti apa-apa. Tradisi maritim dan agraris yang dimiliki masyarakat Banten menambah modal dasar bagi terbentuknya Banten sebagai Kota Pelabuhan. Hal lain yang perlu digarisbawahi ialah kemampuan masyarakat Banten mengolah "pengaruh dari luar" (dalam arti luas) untuk diintegrasikan dan dikembangkan.

\section{DAFTAR PUSTAKA}

Ambary, Hasan Muarif. 1997. Agama dan Masyarakat Banten, Kumpulan Makalah Diskusi, Banten Kota Pelabuhan Jalan Sutra, Jakarta: Depdikbud.

Atja dan Ayatrohaedi. 1986.

Nagarakertabhumi 1.5. Jakarta: Dirjen Kebudayaan, Departemen Pendidikan dan Kebudayaan.

Cortesao, Armando. 1944.

The Suma Oriental of Tome Pires. London: The Hakluyt society.

Dartono. 1991.

Penyebaran Agama Islam di Cirebon dan Sekitarnya, Antara Tahun 1470-1570 Masehi. Skripsi Jurusan Sejarah, Fakultas Sastra, UI.

Djajadiningrat, Hoesein. 1983.

Tinjauan Kritis Tentang Sejarah Banten: Sumbangan Bagi Pengenalan Sifat-sifat penulisan Sejarah Jawa, Jakarta: penerbit Djambatan.

Ekadjati, Edi S., et al.1984.

Pengaruh Pelita terhadap Kehidupan Masyarakat Desa di Jawa
Barat. Jakarta: Depdikbud, Proyek IDKD.

1991.

Sejarah Perkembangan Pemerintahan Provinsi Daerah Tingkat I Jawa Barat. Bandung: Pemerintah Provinsi Daerah Tingkat I, Jawa Barat.

Kartodirdjo, Sartono. 1987.

Berkunjung ke Banten Satu Abad yang Lalu (1879-1888). Makalah yang disampaikan pada Hari Jadi ke-462. Pemerintah DT II, Kabupaten Serang.

Knaap, Gerrit. 1995.

"Shiping and Trade in Jawa, ca. 1775: A Quantitative Analysis", Makalah pada Ceramah Ilmiah di Program Pasca Sarjana UNPAD, Bandung.

Lasmiyati, et. al. 2006.

Sejarah Kota Banten Lama (di Provinsi Banten,) Bandung Departemen Kebudayaan dan Pariwisata, Balai Kajian Sejarah dan Nilai Tradisional.

Michrob, Halwany. 1993.

Catatan Masa Lalu Banten. Serang, Banten: Saudara.

Rahardjo, Supradikus dan Wiwin Djuwita. 1994.

Kota Daerah Sebagai Bandar Dagang di Jalur Sutra. Jakarta: Depdikbud.

Tjandrasasmita, Uka. 1987.

Banten sebagai Pusat

Kekuasaan dan Niaga Antar Bangsa, Kumpulan Makalah Diskusi, Banten Kota Pelabuhan Jalan Sutra. Jakarta: Depdikbud, RI. 
Patanjala Vol. 2, No. 1, Maret 2010: 80-94

Sudjana, T.D. 1995.

"Pelabuhan Cirebon Dahulu dan Sekarang”. Jakarta: Depdikbud.

Sedyawati, Edi dan A.B. Lapian. 1995. "Peranan Politik Bandar Cirebon". Cirebon: Depdikbud, Ditjen Jarahnitra, Proyek IDSN.

Wiryono, Herry, et al. 2004.

Pergerakan Pembaharuan Islam (Studi Historis tentang Eksistensi Persatuan Islam (Persis) di
Kabupaten Serang, Propinsi Banten). Bandung: BKSNT.

Zuhdi, Susanto. 1996.

Hubungan Pelabuhan Cirebon dengan Pedalaman: Suatu Kajian dalam Kerangka Perbandingan dengan Pelabuhan Cilacap, 1800-1940. Jakarta. KPG (Kepustakaan Populer Gramedia) bekerjasama dengan Yayasan Adikarya IKAPI dan The Ford Foundation. 